
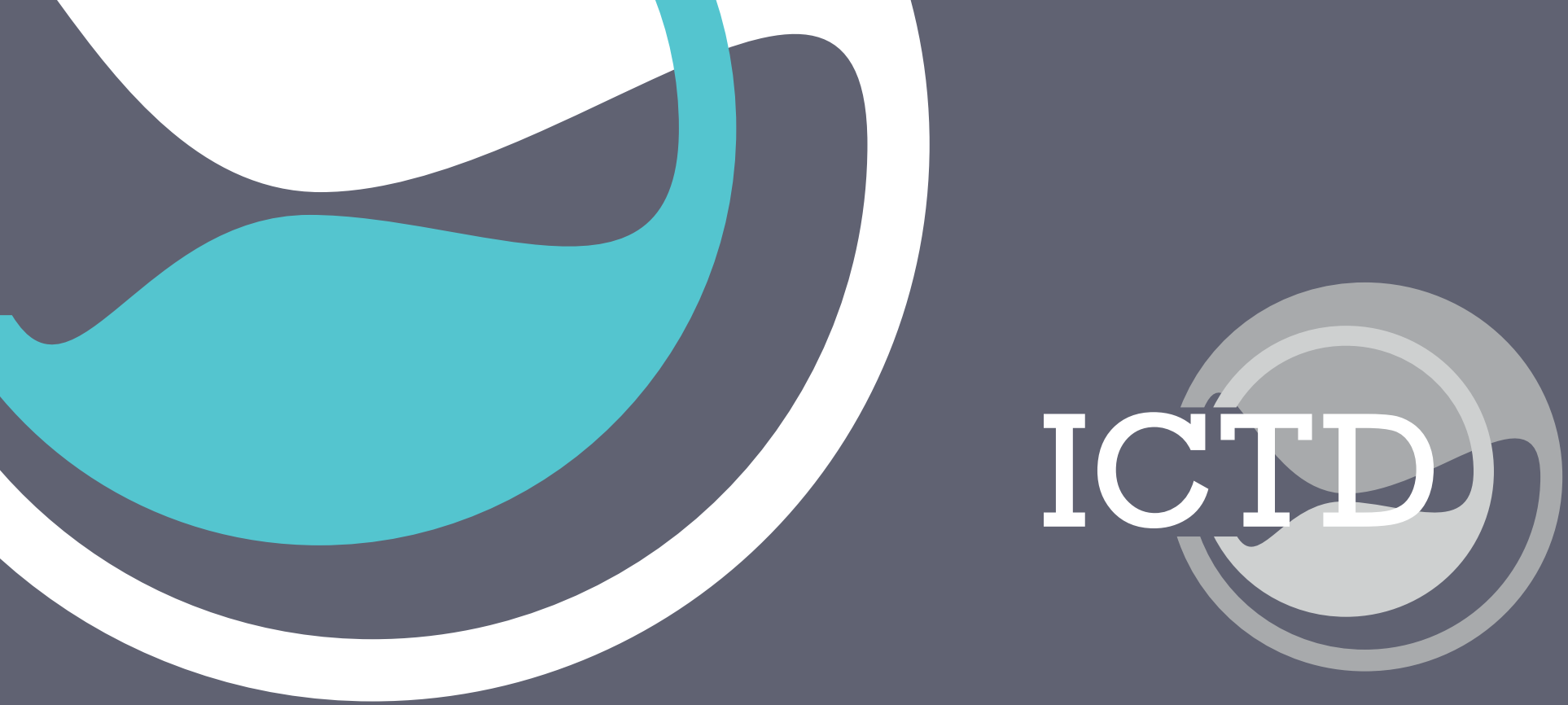

Working Paper 115

At the Table, Off the Menu? Assessing the Participation of Lower-Income Countries in Global Tax Negotiations

Rasmus Corlin Christensen, Martin Hearson and Tovony Randriamanalina

December 2020

BILL $\leftrightarrow$ MELINDA

GATES foundation
NR

UKaid
(2) institute of development studies 
ICTD Working Paper 115

\section{At the Table, Off the Menu? Assessing the Participation of Lower-Income Countries in Global Tax Negotiations}

Rasmus Corlin Christensen, Martin Hearson and Tovony Randriamanalina

December 2020 
At the Table, Off the Menu? Assessing the Participation of Lower-Income Countries in Global Tax Negotiations Rasmus Corlin Christensen, Martin Hearson and Tovony Randriamanalina

ICTD Working Paper 115

First published by the Institute of Development Studies in December 2020

(C) Institute of Development Studies 2020

ISBN: 978-1-78118-732-6

DOI: $10.19088 /$ ICTD.2020.004

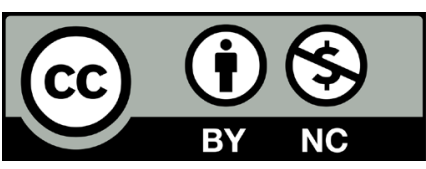

This is an Open Access paper distributed under the terms of the Creative Commons Attribution Non Commercial 4.0 International license, which permits downloading and sharing provided the original authors and source are credited - but the work is not used for commercial purposes. http://creativecommons.org/licenses/by-nc/4.0/legalcode

Available from:

The International Centre for Tax and Development at the Institute of Development Studies, Brighton BN1 9RE, UK

Tel: +44 (0) 1273606261

Email: info@ictd.ac

Web: www.ictd.ac/publication

Twitter: @ICTDTax

Facebook: www.facebook.com/ICTDtax

IDS is a charitable company limited by guarantee and registered in England

Charity Registration Number 306371

Charitable Company Number 877338 


\title{
At the Table, Off the Menu? Assessing the Participation of Lower-Income Countries in Global Tax Negotiations
}

\author{
Rasmus Corlin Christensen, Martin Hearson and Tovony Randriamanalina
}

\section{Summary}

Since 2013, the formal structure of global corporate tax policymaking at the OECD has changed. Decisions are no longer made by 37 OECD members, but by 137 countries from all regions and levels of development through the 'Inclusive Framework' (IF). Official documentation emphasises that all countries participate on an 'equal footing', but some participants and observers have emphasised that developing countries in particular face practical obstacles that lead to unequal participation in practice. In this paper, we assess these claims, drawing primarily on 48 interviews with negotiators, policymakers and stakeholders involved in global tax discussions. We find that the explosion in formal membership has not in itself led to the step-change in developing country influence that the raw numbers imply. This is because of a combination of structural obstacles that are not unique to the IF, and some challenging aspects of the OECD's way of working. Yet, lowerincome countries have made some modest achievements to date, and there are signs of incremental progress towards a more effective presence. We develop a typology of mechanisms through which successes have been achieved: association with the efforts of more powerful states, anticipation of lower-income countries' needs by the OECD secretariat and others, collaboration to form more powerful coalitions, and the emergence of expert negotiators with individual authority.

Keywords: international taxation, multinational enterprises, OECD, Inclusive Framework, negotiations

Rasmus Corlin Christensen was recently awarded his $\mathrm{PhD}$ from the Copenhagen Business School. His main research interest is in the political and professional foundations of the rules and practices of international taxation. Based in Copenhagen, Rasmus works with the ICTD as a consultant on research and policy engagement related to global negotiations on taxing the digital economy.

Martin Hearson is Research Fellow at the International Centre for Tax and Development at the Institute of Development Studies. He researches the politics of international business taxation, and in particular the relationship between developed and developing countries. He was previously a fellow in international political economy at the London School of Economics and worked in the charity sector for a decade.

Tovony Randriamanalina is an independent researcher who studies the appropriateness of the transfer pricing rules in the particular case of developing countries. She has a PhD in International Tax Law from the University of Paris-Dauphine. Prior to her academic work, Tovony was a Tax Official at the Malagasy Revenue Authority, and is a graduate of the National School of Administration of Madagascar. 


\section{Acknowledgements}

We are grateful to all the anonymous interviewees who were generous with their time and reflections. Our thanks also go to the Centre for Tax Policy and Administration in the OECD secretariat, who shared data on meeting attendance with us and offered comments and suggestions from the outset. Aleix Montana and Katharina Kuhn provided excellent research assistance. Our colleagues at ICTD and two anonymous reviewers offered helpful comments.

\section{Acronyms}

$\begin{array}{ll}\text { AOA } & \text { Authorized OECD Approach } \\ \text { ATAF } & \text { African Tax Administration Forum } \\ \text { BEPS } & \text { Base erosion and profit shifting } \\ \text { CBCR } & \text { Country-by-county reporting } \\ \text { CIAT } & \text { Inter-American Center of Tax Administrations } \\ \text { CREDAF } & \begin{array}{l}\text { Centre de Rencontres et D'études des Dirigeants des Administrations Fiscales/ } \\ \text { Exchange and Research Centre for Leaders of Tax Administrations }\end{array} \\ \text { G20 } & \text { Group of 20 } \\ \text { G24 } & \text { Intergovernmental Group of 24 } \\ \text { IF } & \text { Inclusive Framework } \\ \text { MNEs } & \text { Multinational enterprises } \\ \text { OECD } & \text { Organisation for Economic Co-operation and Development } \\ \text { PE } & \text { Permanent establishment } \\ \text { SEP } & \text { Significant Economic Presence } \\ \text { SGATAR } & \text { Study Group on Asian Tax Administration and Research } \\ \text { UN } & \text { United Nations } \\ \text { WP6 } & \text { Working Party } 6 \text { on the Taxation of Multinational Enterprises }\end{array}$




\section{Contents}

Summary 3

Acknowledgements 4

Acronyms 4

Introduction $\quad 6$

$1 \quad$ Background: inclusiveness in international tax policy $\quad 7$

2 Data and methods 9

$3 \quad$ The organisation of global tax policy decision making 10

3.1 Lower-income country participation at the IF 12

3.2 Barriers to lower-income country involvement 13

$\begin{array}{ll}3.3 & \text { Looking beyond the numbers } \\ \end{array}$

$4 \quad$ Cases of lower-income country influence 16

$5 \quad$ Mechanisms of lower-income country influence 18

$\begin{array}{lll}5.1 & \text { Association } & 19\end{array}$

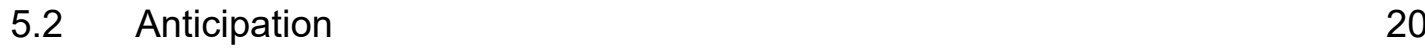

5.3 Collaboration 23

$\begin{array}{ll}5.4 & \text { Individual authority } \\ & 26\end{array}$

$6 \quad$ Conclusions and recommendations 28

$\begin{array}{ll}\text { References } & 32\end{array}$

Figures

Figure 1 The evolution of global tax inclusiveness 9

$\begin{array}{lll}\text { Figure } 2 & \text { Timeline of policy cases } & 17\end{array}$

Tables

Table 1

Table 2

Table 3

Composition of interviewees $\quad 10$

Comparing formal political membership to standard-setting participation 12

Participation by non-OECD delegates varies by country groups $\quad 13$

$\begin{array}{lll}\text { Table } 4 & \text { Mechanisms of lower-income country influence } & 18\end{array}$

Boxes

Box 1

$\begin{array}{ll}\text { Sixth method } & 19\end{array}$

Box $2 \quad$ Country-by-country reporting 21

Box $3 \quad$ Technical services fees (UN Tax Committee) 22

Box $4 \quad$ Significant Economic Presence 24

$\begin{array}{lll}\text { Box } 5 & \text { Authorized OECD Approach } & 27\end{array}$ 
If you're talking about Africa and low-income countries, then definitely there's a huge silence, there's just very few [lower-income countries] that have a voice, despite some of them having a seat in the Inclusive Framework. Because you know having a seat is definitely not enough, and I think that's the biggest criticism of the official OECD presentation of the IF.

(Former official from an emerging market country)

\section{Introduction}

For half a century, the most influential international rules and standards for taxing multinational corporations have been formulated by a select group of developed countries, the OECD, with lower-income countries on the outside. ${ }^{1}$ The resulting standards are frequently criticised for being inappropriate to developing countries' needs. These rules, it is argued, are complex and indeterminate, meaning that countries with limited administrative resources are more vulnerable to tax avoidance (Durst 2019; Picciotto 2018). Furthermore, the fairness of the way in which they distribute the right to tax multinationals' profits has been questioned (Brooks and Krever 2015; Christians and van Apeldoorn 2018a; Eyitayo-Oyesode 2020).

Since 2013, the institutional picture has changed, offering hope that this situation might change too (Mason 2020). At the direction of the Group of 20 (G20), decision making at the OECD has moved from the confines of OECD membership to the 'Inclusive Framework' (IF), which today encompasses 137 jurisdictions. When it was created in 2016, the number of countries with a formal standing in the OECD's tax work doubled. Instead of the slogan 'if you're not at the table, you're on the menu', a more complicated metaphor is now needed, taking into account the drafting of recipes, seating arrangements and catering for countries' different dietary requirements.

With 137 countries involved, the challenge is to simultaneously satisfy many new and diverse needs and maintain a coherent system of rules and rule-making procedures. Critics argue that the result is a lack of real inclusiveness (Christians and van Apeldoorn 2018b; Ndubai 2019). The African Tax Administration Forum (ATAF), an IF observer, has noted that 'the likelihood that officials in [African] countries are able to regularly attend meeting[s] is quite slim. When they are able to, more often than not, limited capacity means they struggle to influence the decision-making process' (ATAF 2019: 12). Those tasked with overseeing policy, however, insist that, while handicapped by capacity constraints, lower-income countries are having a real impact (Dickinson 2019; Inclusive Framework 2020; OECD 2020b).

Where does the truth lie? This paper considers how lower-income countries have made use of the IF's standard-setting opportunities. We draw on interviews conducted in late 2019 and 2020 with 48 negotiators, policymakers and other stakeholders. We also examined attendance records from OECD working party meetings and published policy documents. We assessed seven OECD and IF policy case studies and one comparison case at the United Nations (UN) Tax Committee.

We find that the IF's expansion has made little difference to the number of lower-income countries attending meetings at which the practical technical policy work is done, and that

In this paper, we define lower-income countries as those in the World Bank's 'low' and 'lower middle' income classification, which are not OECD or G20 members. We use three additional country classifications: OECD members, non-OECD G20 countries, and others. 'Non-OECD G20 countries' includes Argentina, Brazil, China, India, Indonesia, Russia, Saudi Arabia and South Africa. 'Others' comprises the remaining upper-middle and high-income countries and jurisdictions, including a number of offshore financial centres. 
most members are fairly silent participants. This is partly because of well-documented structural obstacles not unique to the IF, but is exacerbated by some aspects of the OECD's decision-making processes, such as the pace and intensity of discussions, the culture of policymaking, the costs of attending regular meetings in Paris, and the absence of routine and timely translation of documents and meetings. This can make the OECD a daunting environment for member state delegates, but especially for those from lower-income countries. In addition, many have joined with no intention of influencing standards, but rather in pursuit of technical assistance or prestige, or under coercion from the European Union.

This is not the whole story, however. The most successful mechanisms of influence do not rely on raw numbers alone, or even on formal IF membership. In practice, the interests of lower-income countries are often advanced by a few influential individuals. Some are from lower-income IF member countries, but others are from non-IF countries in observer roles, secretariats of international and regional tax organisations, G20 and OECD countries, or civil society organisations.

Drawing on the literature on lower-income countries' participation in economic diplomacy, we identify four change mechanisms in favour of lower-income countries.

- First, lower-income countries can make the most of reforms pursued by more powerful OECD or G20 states, leading to change by association.

- Second, influential individuals, including secretariat staff and delegates from more powerful countries, can anticipate and promote lower-income country interests.

- Third, collaboration among lower-income countries, and with other countries with common interests, can bolster the influence of key delegates. Such collaborations are exemplified by the Group of 24 (G24) and ATAF.

- Fourth, individual authority in negotiations comes from having people with expertise, personal experience and networks representing lower-income countries.

Although achievements through these dynamics to date are modest, there are signs of incremental progress towards more effective participation. To enhance this further, we suggest several practical recommendations aimed at donors, international organisations and lower-income countries themselves, which could strengthen collaboration by lower-income countries, address structural obstacles, and improve the effectiveness of expert negotiators.

Our analysis is limited to established institutional settings, in particular the OECD and the IF. We provide the first comprehensive, micro-level, comparative account of lower-income countries in these institutions. We have not set out to interrogate institutional legitimacy, nor to draw conclusions about the whole global tax system. Our analysis does shed light, however, on the appropriateness of particular institutional forms for addressing current cooperation needs.

\section{Background: inclusiveness in international tax policy}

For almost a century, the core international tax rules and the main states involved in designing and revising them have remained surprisingly stable. Nonetheless, throughout this period, debate between 'developed' and 'developing' countries over the content of international tax rules has been intertwined with tensions concerning the institutions in which they are set (Hearson 2021; Jogarajan 2018). 
When the OECD's predecessor the OEEC began to consider working on tax cooperation in the 1950s, proponents observed that it would be easier to make progress 'within a group of like-minded nations' than had been possible among the more diverse memberships of the League of Nations and UN (OEEC 1956: 1). An ad hoc group of UN experts, now the UN Tax Committee, was subsequently created, but by the time it published its Model Convention in 1980 the OECD had become, in its own words, the 'market leader in developing tax standards and guidelines' (cited in Christians 2010: 2). Lower-income countries' international tax agreements still bear more resemblance to the OECD's model than the UN's (Hearson 2016; Wijnen and de Goede 2014).

Since the turn of the 21st century, the OECD's leadership position in international tax cooperation has been challenged on both 'input' and 'output' grounds. Input legitimacy refers to the process of standard setting, given the unrepresentative nature of OECD membership. First, this undermined efforts to coerce offshore financial centres into compliance with OECD standards (Sharman 2006), and after the global financial crisis the OECD realised that it needed the support of large emerging economies to maintain its leadership position (Mason 2020). In parallel, lower-income countries and civil society organisations began expressing concerns about the UN's marginalisation in tax cooperation (Lesage, McNair and Vermeiren 2010; Mminele 2015). In output terms, the ambiguity and complexity of OECD standards has created questions about their suitability to the legal and administrative context of resourceconstrained lower-income countries (Valderrama 2018). These same issues eventually led to a crisis of legitimacy in OECD states themselves, as corporate tax avoidance became front page news (Christensen and Hearson 2019).

In response, the OECD has expanded its standard-setting tent. For corporate taxation, it has done so in several steps (see Figure 1). First, the Base Erosion and Profit Shifting (BEPS) project welcomed eight non-OECD G20 countries, plus Colombia and Latvia, into the policymaking tent as 'associates' (OECD 2014). From January 2015, other countries and regional bodies were invited to attend standard-setting meetings. While they did not have a formal right to participate in decision making, OECD literature was optimistic that '[n]ot only will developing countries be able to directly input and gain an improved understanding of the BEPS process, but OECD members and BEPS Associates will also be exposed first-hand to accounts of the specific perspectives of, and challenges faced by, developing countries'. ${ }^{2}$ By May 2015, 62 countries were 'directly engaged in the development of BEPS measures'. ${ }^{3}$ The lower-income countries among them were Bangladesh, Kenya, Nigeria, Morocco, Philippines, Senegal, Tunisia and Vietnam. ${ }^{4}$

That same year, the G20 endorsed the OECD's plans to establish the IF 'with the involvement of interested non-G20 countries and jurisdictions which commit to implement the BEPS project, including developing economies, on an equal footing' (G20 2015: 15). The IF's remit covers 'developing standards on BEPS related issues and reviewing and monitoring the implementation of the whole BEPS Package' (OECD 2020a). Membership now stands at 137 countries.

OECD (2014) 'The BEPS Project and Developing Countries: From Consultation to Participation', www.oecd.org/ctp/strategy-deepening-developing-country-engagement.pdf, p2.

OECD (2015) 'Meeting of the Council at Ministerial Level, 3-4 June 2015', C/MIN (2015) 8, www.oecd.org/officialdocuments/publicdisplaydocumentpdf/?cote=C/MIN(2015)8\&docLanguage=En, $\mathrm{p} 4$. Colombia, Latvia and Lithuania have subsequently joined the OECD. 
Figure $1^{5}$

\section{The evolution of global tax inclusiveness}

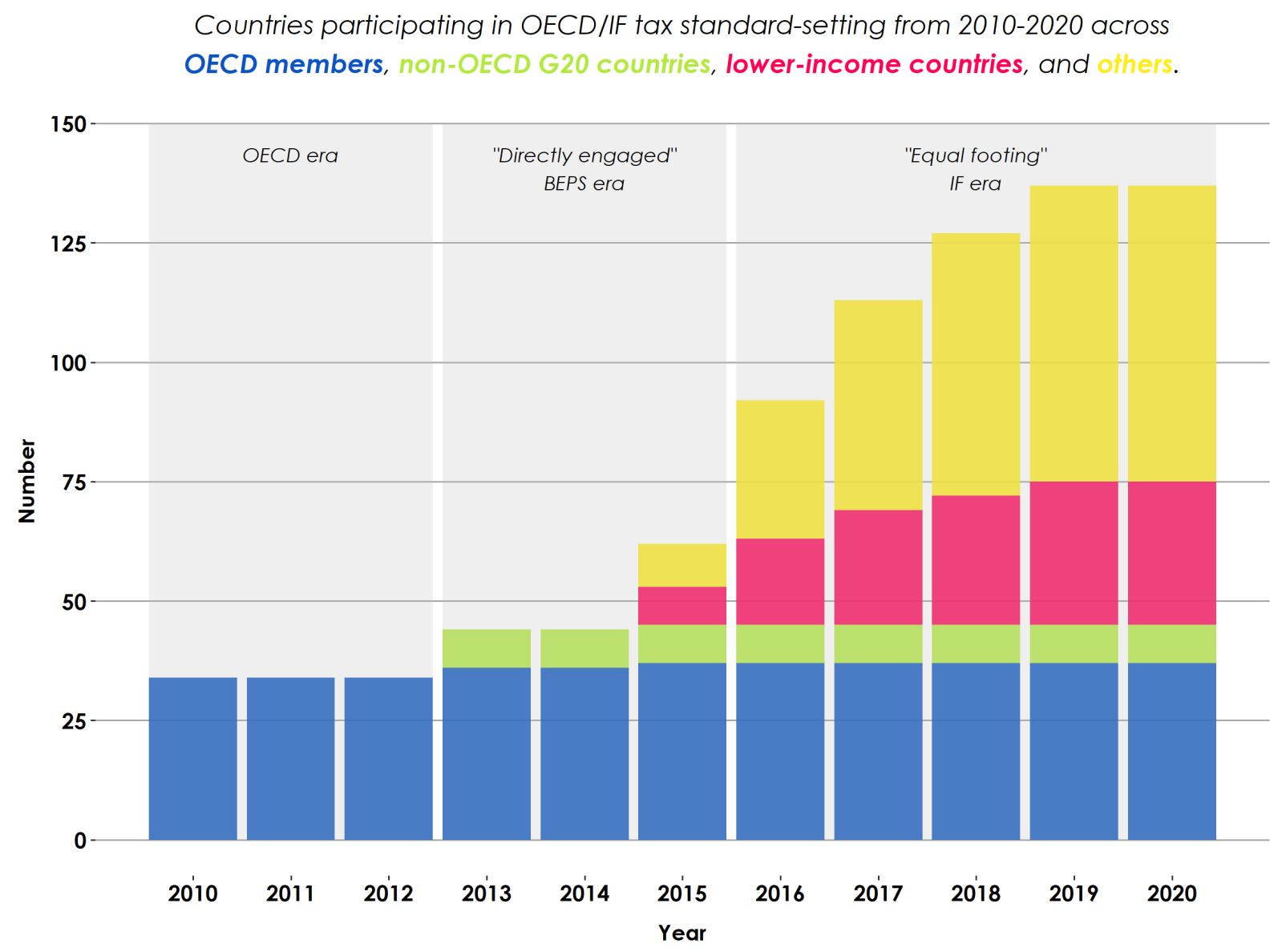

OECD-centric tax standard setting is hardly alone among global governance regimes in undergoing this opening up process, but it is unique because the expansion happened so rapidly. In trade governance, for example, lower-income countries had been signing up to the General Agreement on Trade and Tariffs (GATT) for decades before a critical mass challenged the historical core (Michalopoulos 1999). Tax multilateralism, then, offers a particularly intriguing research context as an almost 'overnight' experiment in mass integration of lower-income countries into Northern-led global governance.

\section{Data and methods}

We draw evidence from three sources: attendance records, interviews and policy documents. Our first source was participation records from OECD working party meetings between 2015 and 2019 , kindly supplied by the OECD secretariat. This allowed us to identify countries to prioritise for interviews and permitted the descriptive quantitative analysis in Section 3.

Second, we conducted semi-structured interviews with 48 negotiators, bureaucrats and stakeholders involved in global tax policymaking (see Table 1). Given 2020's travel restrictions, most interviews were by phone or videoconference. Our sampling was strategic, targeting a representative sample from three groups: government officials, civil servants at the OECD secretariat and other international organisations, and other stakeholders. A draft 
of this paper was reviewed by the OECD secretariat, who supplied written comments and met with us to discuss our analysis.

Table 1 Composition of interviewees

\begin{tabular}{|c|c|c|}
\hline Characteristics & Count & Proportion \\
\hline \multicolumn{3}{|l|}{ Sex } \\
\hline Male & 29 & $60 \%$ \\
\hline Female & 19 & $40 \%$ \\
\hline \multicolumn{3}{|l|}{ Current role } \\
\hline National delegate/representative & 21 & $44 \%$ \\
\hline International bureaucrat & 7 & $15 \%$ \\
\hline Regional tax organisation & 6 & $13 \%$ \\
\hline Other & 14 & $29 \%$ \\
\hline \multicolumn{3}{|l|}{ Region (nationality) } \\
\hline East Asia and Pacific & 3 & $6 \%$ \\
\hline Europe and Central Asia & 15 & $31 \%$ \\
\hline Latin America and Caribbean & 8 & $17 \%$ \\
\hline Middle East and North Africa & 1 & $2 \%$ \\
\hline North America & 3 & $6 \%$ \\
\hline Sub-Saharan Africa & 18 & $38 \%$ \\
\hline
\end{tabular}

At first, we followed an open-ended approach in interviews, identifying themes and specific policy cases. Later, we adopted a more structured technique, looking for evidence to confirm or deny our emergent understandings. Subsequently, we followed a process of qualitative coding to identify themes in our interview notes and transcripts (Clarke, Braun and Hayfield 2007; Schreier 2012). In this paper we use anonymised interview quotes.

Lastly, we complemented interviews and attendance data with content analysis of relevant documents: public policy statements, consultation documents and comment letters, news articles and commentary. We reviewed two sets of documents on each key policy case: (a) every policy-related document - discussion draft, consultation letter, press release, report and guidance - issued by the international organisation as part of the decision-making process, and (b) every article - news story, commentary, policy analysis - published in Tax Notes International, a key outlet for both practitioners and policymakers.

\section{The organisation of global tax policy decision making}

A typical communication following an IF plenary meeting emphasises the endorsement of its full membership.

The Inclusive Framework on BEPS, which groups 137 countries and jurisdictions on an equal footing for multilateral negotiation of international tax rules, decided during its Jan. 29-30 [plenary] meeting to move ahead with a two-pillar negotiation to address the tax challenges of digitalisation. ${ }^{6}$

Behind such statements lies a three-tiered structure of decision making: plenary, Steering Group and working parties. At the top political level, plenaries convene senior tax officials from almost every IF member, alongside observers from regional and international

6 OECD 'International Community Renews Commitment to Multilateral Efforts to Address Tax Challenges from Digitalisation of the Economy', www.oecd.org/tax/beps/international-community-renews-commitment-to-multilateralefforts-to-address-tax-challenges-from-digitalisation-of-the-economy.htm 
organisations. Plenaries evaluate progress and take final decisions, on a consensus basis, on proposals prepared by subordinate bodies. The plenary is the formal decision-making body, and the final step in a process which identifies and resolves disagreements between countries in advance. Many interviewees described its meetings as choreographed:

It is a room of approval where everything has been well prepared and orchestrated (...) the sauce has been made, the dish is served. If you say that the salt is missing, you want to add something (...) they will tell you that the dish is done. It is at the Steering Group level that the dish is prepared.

(Lower-income country)

The most intensive policy negotiations take place within the Steering Group, despite its advisory status. Meeting several times a year, it brings together 24 individuals from countries equally split between members and non-members of the OECD's Committee of Fiscal Affairs. ${ }^{7}$ Steering Group members are nominated by states and formally elected by the IF's membership, but participate in a personal capacity. The election process is heavily steered by the OECD secretariat, which identifies capable and influential individuals, while ensuring geographical balance.

Working parties are technical groups formally open to representatives from all IF member states, typically involve 40 to 60 experts, and meet two to four times per year. Four working parties have the biggest role in standard setting: WP1 on tax treaties, WP6 on transfer pricing, WP10 on exchange of information, and WP11 on aggressive tax planning. Each has an elected chair, co-chair and bureau, who work with the secretariat to steer the standardsetting process.

The OECD bureaucracy consists primarily of its secretariat in the Centre for Tax Policy and Administration. Unlike the OECD's other key global tax standard-setting body, the Global Forum on Transparency and Exchange of Information for Tax Purposes, the IF does not have a separate dedicated secretariat. Instead, a derogation to the usual OECD rules allows its Centre for Tax Policy and Administration to hire staff from IF member states: its staff team includes people from Brazil, Cameroon, China, Colombia, Costa Rica, Egypt, India, Kenya and Pakistan (Dickinson 2019). While the Global Forum secretariat has been headed by Indian and Brazilian nationals since 2012, the OECD has not appointed a head of division or unit from a non-member country for BEPS-related work. Together, the secretariat and the working parties work on technical analyses and policy development. Where possible, political questions are handled at Steering Group level and endorsed in the plenary, although some final decisions on contentious matters are taken in the plenary itself.

While the OECD is often contrasted with the UN Tax Committee as the latter comprises individuals and the former states, the Steering Group and the UN Tax Committee are more similar than this implies. Both are groups of around 25, mixed roughly 50/50 between OECD and non-OECD origins. Experts participate in a personal capacity and secretariats play a central role in determining group composition. Most practical work is organised through focused working groups. There is only a small overlap between the Steering Group and UN Tax Committee (two people at the time of writing), but many UN Tax Committee members are active members of OECD working parties.

There are important contrasts between the two bodies, however. Most obviously, they have different mandates: the latter's includes an obligation to 'give special attention to developing countries and countries with economies in transition' (Economic and Social Council 2004,

This distinction is equal to OECD and non-OECD members with the exception of Argentina, which is not an OECD member but participates in the CFA as an associate. www.oecd.org/tax/beps/steering-group-of-the-inclusive-frameworkon-beps.pdf 
para. (d)(v)). There are also two important institutional differences. First, the IF Steering Group works formally on a consensus basis, whereas the UN Tax Committee can work from majority decision voting. Second, the OECD secretariat is vastly better-resourced than the UN Tax Committee: the former employs over 100 specialists across its tax work (although this capacity does not all support the IF directly), whereas the latter has only a handful of experts on staff.

\subsection{Lower-income country participation at the IF}

Where do lower-income countries participate in this multi-tier structure? We find significant variation across OECD/IF bodies (Table 2). In terms of formal participation, the number of non-OECD countries has increased tenfold from 2013 to 2019. Non-OECD-members now outnumber OECD members by almost three to one, and 22 per cent of IF members are lower-income countries. ${ }^{8}$ Almost all 137 members participate in plenaries with at least one delegate. At policy level, the Steering Group is equally balanced between OECD and nonOECD members, and at the start of 2020 three of its 24 members (12.5 per cent) were from lower-income countries. The strength of participation, however, varies significantly. Across our interviewees, comments concerning the effectiveness of non-OECD Steering Group members were broadly consistent: some were frequently cited as productive negotiators, while others attended erratically or failed to speak up.

Table 2

Comparing formal political membership to standard-setting participation

Proportion of membership and attendance at key bodies (2019) across country groups

\begin{tabular}{lrrr}
\hline Group & Inclusive Framework & Steering Group & $\begin{array}{r}\text { Working Party } \\
\text { attendance }\end{array}$ \\
OECD members & $27.0 \%$ & $50.0 \%$ & $77.4 \%$ \\
\hline Non-OECD G20 countries & $5.8 \%$ & $25.0 \%$ & $10.2 \%$ \\
\hline Lower-income countries & $21.9 \%$ & $12.5 \%$ & $5.4 \%$ \\
\hline Others & $45.3 \%$ & $12.5 \%$ & $7.0 \%$ \\
\hline
\end{tabular}

Experience in the working parties is similarly mixed. Here, lower-income country involvement in practice lags significantly behind formal membership: in 2019 , only 5.4 per cent of working party attendees represented lower-income countries. ${ }^{9}$ The same goes for working party bureaux, where participation by lower-income countries is almost non-existent. An isolated exception is Nigeria, whose representative on WP6 is now a bureau member and its cochair. As a whole, non-OECD countries represent less than 25 per cent of working party attendees, despite making up almost 75 per cent of IF membership. These figures represent a small increase on 2015, prior to the IF's creation, when lower-income country attendance was at 4 per cent, and total non-OECD attendance at 19 per cent.

Further disaggregating the distribution of working party participation reveals highly skewed attendance among non-OECD countries. Out of 100 non-OECD IF members, 70 did not attend a single working party meeting during 2019. Among attendees, participation was heavily dominated by large emerging economies, especially from Asia (Table 3): on average,

\footnotetext{
$8 \quad$ For an explanation of the country categories, see footnote 1.

$9 \quad$ The data supplied by the OECD covers working parties 1, 6, 10 and 11
} 
non-OECD G20 countries participated at 50 per cent of possible working party meetings, while for lower-income countries the number was 4 per cent across 2015-2019.

\section{Table 3}

\begin{tabular}{|c|c|c|c|}
\hline \multicolumn{4}{|c|}{$\begin{array}{l}\text { Participation by non-OECD delegates varies by country groups and regions } \\
\text { Share of possible OECD Working Party meetings attended by non-OECD delegates since joining standard-setting work (2015-2019) }\end{array}$} \\
\hline Country group & Participation $^{1}$ & Region & Participation ${ }^{7}$ \\
\hline Non-OECD G20 & $50 \%$ & South Asia & $19 \%$ \\
\hline Others & $6 \%$ & East Asia \& Pacific & $12 \%$ \\
\hline \multirow[t]{5}{*}{ Lower-income countries } & $4 \%$ & Latin America \& Caribbean & $12 \%$ \\
\hline & & Sub-Saharan Africa & $10 \%$ \\
\hline & & Europe \& Central Asia & $10 \%$ \\
\hline & & Middle East \& North Africa & $2 \%$ \\
\hline & & North America & $0 \%$ \\
\hline
\end{tabular}

\subsection{Barriers to lower-income country involvement}

This low level of participation results from three inter-related causes: broad structural obstacles to participation, specific aspects of the OECD/IF's way of working that exacerbate these issues, and low expectations of the potential gains from participation.

The structural issues consist of resource constraints and political disengagement (see ATAF 2019). ${ }^{10}$ Studies of bilateral treatymaking illustrate how technical officials from lower-income countries are frequently thrust into negotiating environments because of priorities determined by finance ministries, with little prior work to evaluate the risks of participating nor to formulate negotiating positions (Aukonobera 2012; Hearson 2021; Mutava 2019; Quinones Cruz 2012). Negotiators need strong technical and political backing, including the resources to prepare for and participate in negotiations and a mandate to stick to contentious positions. Without this, outcomes are inevitably heavily skewed towards their negotiating partners.

Many interviewees stated that they could not justify extensive participation in IF negotiations when it would create opportunity costs back home. Many felt that their political principals are not adequately engaged, and their finance ministry colleagues unfamiliar with what IF membership entails. Several described how the push to join the IF had come from their finance ministry, unaware of the compliance and participation costs. ${ }^{11}$ Indeed, some countries have not joined the IF because of advocacy by the revenue authority.

Policymakers are like, 'this sounds great, let's rush in' ... We would come back to the ministry and talk again and again about the IF... At this point [our country] has made that [assessment] a lot of times, and we're still not where the benefits outweigh the costs. (Lower-income country)

\footnotetext{
10 Weak participation by lower-income countries is not unique to taxation but common across global policy areas Literature on trade negotiations, for instance, highlights that technical capacity and intra-governmental coordination are key for lower-income countries to effectively participate in technically complex policymaking (Apecu 2013).

11 Some countries' decisions to join result from coercive pressures, in particular the threat of EU blacklisting (Collin 2020).
} 
Obviously if you had asked me would you support to join the IF, as a tax administration I would have said no. But now we are there we are trying to make the most of it. (Lower-income country)

Several IF-specific factors make meaningful participation harder. The first is the financial and human resource commitment for international tax specialists to travel to Paris. Even if travel funding is sometimes available from donor agencies or from the OECD, this cannot cover all the costs of participation, especially the opportunity costs:

To go to Paris for a working party for a week or two, you've got to have flights and hotels in Paris and you've got to pay people a subsistence allowance for a few days, it's incredibly expensive. (Regional tax organisation)

Bigger countries have bigger resources, and they have teams dedicated to reading and commenting on the OECD documents. I can tell you first-hand, I was sometimes reading a document on the plane, and while I was at the OECD I still had to run my department and do my day job, and try to participate in the meeting.

(Non-OECD G20 country)

The move to online meetings during 2020 has reduced attendance costs, allowing more to participate, but disadvantages include the absence of informal interactions that help newer participants to build relationships with more experienced counterparts.

The speed of policymaking is another major concern. While time pressures are sometimes a political necessity, a trade-off with meaningful inclusive participation must be recognised. As one interviewee said, '[o]ne of the things I learnt quickly was, you don't keep on top of all the papers coming out, and they will move on, and before you know it you've agreed to a position because you haven't voiced a reservation' (non-OECD G20 country). ATAF recently stated, '[many African] countries are becoming concerned that the gap is widening between the pace of change in global standard setting and their capacity to address the implementation challenges these changes would bring to Africa (...) to the point where African countries would simply not participate despite agreements being signed at a political level' (ATAF 2019: 16).

A further difficulty is what some participants described as a 'brutal' and 'intimidating' environment, especially in working party meetings. According to one, 'most delegations are afraid of saying something that will be corrected by a developed country delegate' (other country). A high barrier in terms of technical knowledge is combined here with social discipline, and several delegates related instances in which they had felt frustrated because they did not know - or did not like - the informal rules of the game.

This challenging environment is compounded for some by the demands of working in a foreign language. While the largest meetings and most important documents are translated, Steering Group meetings are not, and documents produced on tight timescales are initially circulated without translation. 'Most work is conducted in English and the documents and notes are also in English. Sometimes documents in [our language] arrive before the meeting, but quite late' (lower-income country). For many lower-income countries, this creates a double disadvantage, making it harder to discuss positions within government, as well as to intervene in Paris.

Rapid timelines contribute to the third main concern: the perception that IF negotiations are structured around the needs, priorities and agendas of larger economies and that lowerincome countries have little option but to acquiesce. 
Sometimes a 'consensus' is achieved simply because developing countries don't want to delay the process. (Regional tax organisation)

There's a heck of a lot of pressure on a small country not to deny consensus, a huge pressure not to hold up the room. (OECD country)

Many countries have joined the IF or sent delegates to meetings without any expectation of having practical influence over standard-setting. Lower-income country officials, observers and stakeholders are pragmatic about the claims of being on an 'equal footing', or of balanced representation. They recognise that the IF is focused on OECD instruments and dominated by larger economies. Although many see value in participating, this does not come from the expectation of transformative influence:

I've never experienced a feeling of not being allowed to express my views, I freely express my views and I get the feeling that they are heard. But I don't expect to have any influence ultimately when decisions are made.

(Other country)

Naturally they are focusing on the OECD model [treaty]. The OECD position is preset and even if you are at the table, they are not going to do things different. [Our] model follows the UN and ATAF, and the OECD is not going to become more sourcebased... [this] is where I am least active because my views are completely different and I don't want to rock the boat. (Lower-income country)

When we were writing the [transfer pricing guidelines], we came and said 'look, there are other approaches' and people were like, 'what are you talking about? We have an OECD approach; we are developing this as an OECD document.'

(Lower-income country)

\subsection{Looking beyond the numbers}

Both the low numbers of lower-income countries participating, and their low expectations, imply pessimism about their capacity to influence. However, our case studies give grounds for optimism. Key to this is the reported effectiveness of certain attendees' interventions. One WP6 member from an OECD country spoke of particularly 'strong voices' from lower-income countries in the 2019 digital tax discussions: '[In] OECD [working party] meetings, the contributions are probably at least as many from certain IF members [as] from OECD countries.' Thus, it is worth emphasising that the numbers of countries attending or speaking are not on their own reliable guides to the extent of successful influence. Secretariat officials made this clear:

We live in a fiction of 137 members who all have a say. You have groups of countries, and even for the G5 [France, Germany, Spain, Italy and the UK], it's enough for one to be in the meeting. For African countries you don't need 40 countries at the table, it's not the right use of resources. (International organisation)

As long as they have two-three delegates who can speak, then they can just preserve their voice and vote at the end. And that's the way it works on both sides. (International organisation)

The number and nature of participants can profoundly affect a discussion's dynamics. In our interviews, we sought to understand how lower-income countries' interests have been taken into account in IF negotiations despite the small number of active participants. The next 
sections elaborate on examples of influence, then the mechanisms through which they took place.

\section{Cases of lower-income country influence}

This section provides an overview of the policy developments from 2012 to 2019 on which we have focused. Based on our initial interviews and documentary analysis, we identified eight policy decisions around which to structure our research (Figure 2). ${ }^{12}$ Three were from the 'BEPS era', from 2013 to 2015. At this point, lower-income countries did not have formal standing at the OECD, but despite this, claims of influence have been made by the OECD itself, by our interviewees or by a regional tax organisation. ${ }^{13}$ This includes:

- the incorporation of the 'sixth method' for transfer pricing assessment that is prevalent in Latin America into the OECD transfer pricing guidelines (TPGs);

- the introduction of country-by-country reporting rules for multinational enterprises (MNEs), along with minimum standards for countries concerning the collection and exchange of these data; and

- the omission of a requirement to participate in mandatory binding arbitration from the BEPS minimum standard on dispute resolution, and from the default options in the BEPS multilateral instrument.

We were unable to find evidence that lower-income countries had been the prime movers behind these decisions. Instead, they were driven by OECD members and non-OECD G20 countries, such as Argentina, India and South Africa. The outcomes have not been adopted widely by lower-income countries, and we did not find evidence that this is likely to change.

12 Our criteria were: (1) Decisions should concern standard setting of global corporate tax rules. (2) They needed to be clear, distinct, and final policy decisions - resulting in the change (or not) of international standards. (3) There needed to be a defined preference on the part of (some) lower-income countries for the content of (non-)change of standards. (4) Decisions should have been attributed by some actors, at least partly, to lower-income countries' actions. (5) Suggested cases needed to be corroborated in enough interviews to provide adequate data. (6) We stopped the timeline for cases in early 2020, to avoid studying moving targets.

13 Other components of the BEPS package, such as limitations on interest deductions and treaty anti-abuse rules, were also sometimes cited as being outcomes beneficial to lower-income countries but not attributed to their actions. 


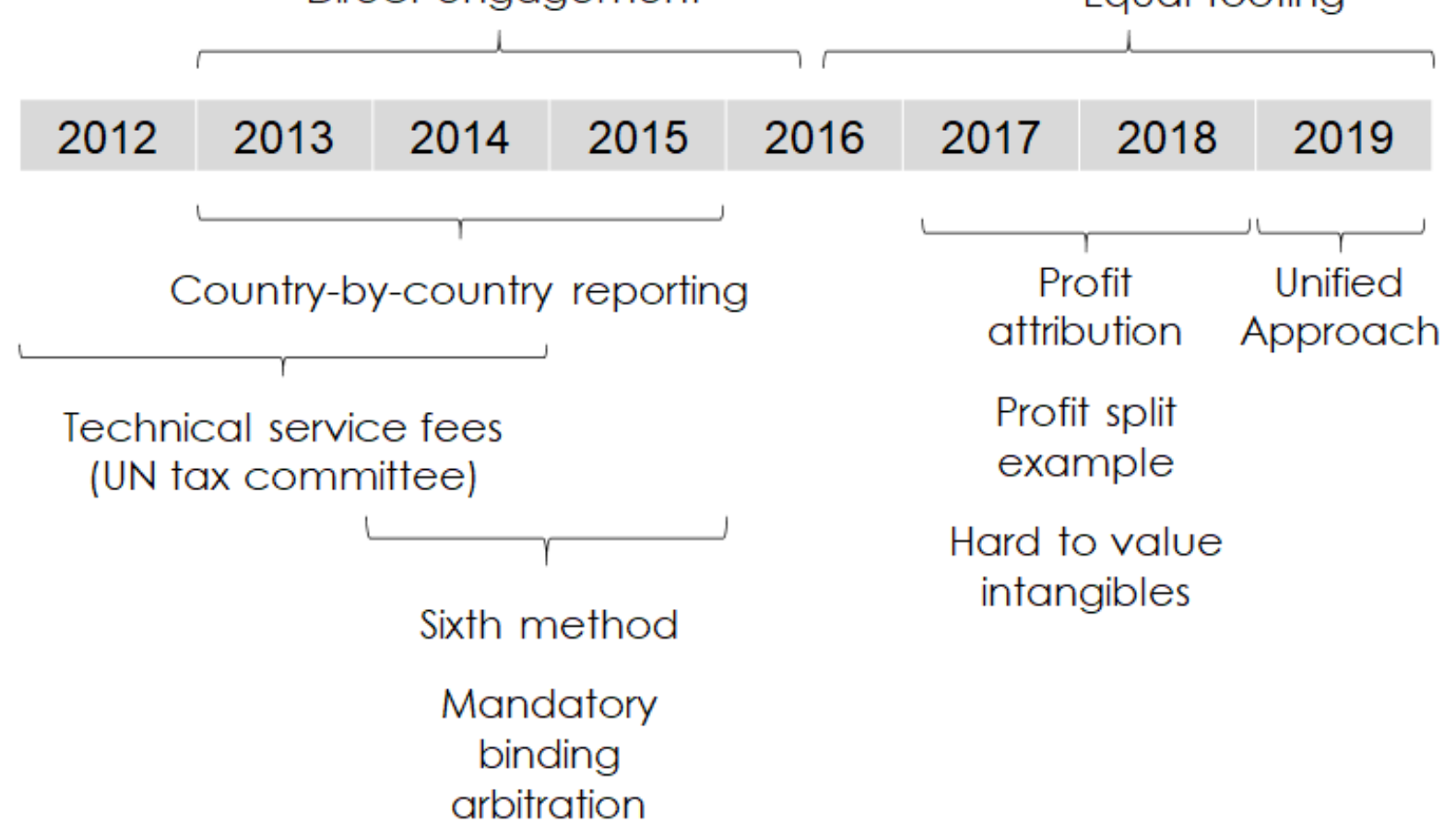

In the IF era, from 2016 onwards, formal political membership expanded significantly. We analysed four decisions from this period:

- inclusion of language in the guidance on attribution of profits to permanent establishments underlining that some countries did not support the Authorized OECD Approach incorporated into the OECD model treaty in 2010;

- inclusion of a practical example based on a business model common in African countries into the TPGs' section on the application of the profit split method;

- recognition of the possibility of ex-post evaluations of transactions involving hard-tovalue intangibles;

- the development of a Unified Approach to update international rules in response to the challenges of digitalisation of the economy, after three proposals were circulated by IF members, one of them the G24's on Significant Economic Presence (SEP).

In most, there is clear evidence that lower-income countries put forward proposals themselves, primarily in WP6 and the Steering Group. ${ }^{14}$ The record of success here is positive for small changes aimed at securing lower-income countries' policy space. The only major change proposed (in part) by lower-income countries - Significant Economic Presence - had little impact in technical terms, but influenced the terms of debate.

Finally, in the comparative case from the UN Tax Committee from 2012-2014, we examined the debate on an article on fees for technical services. The new article included in the UN Model Tax Convention is the most tangible political change that constitutes a success on the part of lower-income countries in changing global tax standards.

14 Other IF discussions, including on financial transactions and the TPGs' concept of control, were also mentioned as results of proactive lower-income country engagement, but we were not able to gather enough evidence to evaluate them. 


\section{Mechanisms of lower-income country influence}

Literature on economic diplomacy points to two broad areas through which lower-income countries' success or failure in negotiations can be explained. First, much literature looks at the ability of whole states to form and benefit from coalitions as critical to success (Kahler and Odell 1989; Narlikar 2003). When faced with opposition from more powerful countries, lower-income countries need alliances with enough economic weight to be influential, and enough coherence to remain united through the endgame of negotiations. Large emerging markets bring economic clout and considerable negotiating capacity, and benefit from the strategic importance of leadership roles, and from appeals to fairness, justice and developmentalism (Hopewell 2015; Narlikar 2010; Vickers 2013). Yet countries' interests are never perfectly aligned, and some blocs are more successful than others at building and maintaining a common position.

A second tendency in the literature focuses on the individuals who negotiate, and on two insights in particular. First, the positions a negotiator can take is shaped by their domestic context, and the need to retain the support of their principals (technocratic managers, politicians or special interest groups). Negotiators are, in effect, negotiating with domestic and international constituencies simultaneously (Bayne and Woolcock 2011; Putnam 1988). Second, negotiators' capabilities depend on them mastering technical detail and navigating the political contours of a transnational expert community, especially difficult for new entrants (Adler and Pouliot 2011; Checkel 2005; Johnston 2008). The OECD is often identified as a setting in which expert communities exert considerable influence over negotiations (Heydon 2011; Marcussen 2001).

We have combined these theoretical perspectives with interview evidence to develop a typology of mechanisms that can create change favourable to lower-income countries (see Table 4). We distinguish between mechanisms in which lower-income countries drive change, and those in which others lead. The first two mechanisms are led by other countries: association is a state-centric mechanism in which small states piggy-back on the actions of larger states, while anticipation refers to actions taken by secretariat staff or other delegates on behalf of lower-income countries. The remaining two mechanisms place lower-income countries in the driving seat: collaboration is a state-centric mechanism occurring when lower-income countries build alliances themselves or with emerging markets, while individual authority refers to leadership by experts representing lower-income countries. While conceptually distinct, there is significant interplay between these mechanisms, and often they are mutually reinforcing. For brevity, our analysis will focus on detailed discussions of selected cases among those listed in Section 4 - those that best represent the four dynamics at play. Brief descriptions of each will be given in info boxes.

Table 4 Mechanisms of lower-income country influence

\begin{tabular}{|l|l|l|l|}
\hline \multicolumn{2}{|l|}{} & Driver of change \\
\cline { 3 - 4 } \multicolumn{2}{|l|}{} & $\begin{array}{l}\text { Lower-income } \\
\text { countries }\end{array}$ & Others \\
\hline \multirow{2}{*}{ Level of analysis } & States & Collaboration & Association \\
& & & \\
\cline { 2 - 4 } & Individuals & Individual authority & Anticipation \\
\hline
\end{tabular}




\subsection{Association}

Often, lower-income countries benefit from positions advanced by larger, more powerful states, without active mobilisation themselves. Association is best understood as the spillover benefits to lower-income countries from the actions of OECD members or, more frequently, of large emerging economies. It has become more common as countries such as Argentina, China and India have become more influential in historically Northern-dominated institutions, especially through the G20. While many benefits take the form of institutional reforms (e.g. the expansion of IF membership), we focus on changes to international standards. Non-OECD G20 countries may share preferences with lower-income countries because of similarities in their economic structures, e.g. a reliance on exports of primary commodities. Commonalities may also operate at the level of ideas, e.g. about fairness and inclusivity. However, association is also the dynamic in which lower-income countries have least agency, and emerging economies do not always have the same interests as lowerincome countries.

\section{Box 1 Sixth method}

Used in Latin American countries and in Zambia, this is premised on 'shortcutting' a full transfer pricing analysis for commodities by using market prices as pricing points. It was promoted at the OECD by a Latin American coalition supported by other resource-rich emerging market and lower-income country stakeholders in the context of BEPS Action 10 on transfer pricing, but met a strong backlash. According to an OECD-country negotiator, it 'ran against some very strong opposition from some countries, some delegates - I could mention the US - saying we don't want this mentioned at all in the Guidelines... So that opposition was quite clear... and meant it was very watered down'. A compromise solution was eventually adopted in the TPGs, in which market prices were accepted as reference points for use in a transfer pricing analysis under the Comparable Uncontrolled Price (CUP) method, without specifying the detailed implementation. A key element of the original Argentinian method, in which the market price is determined on the basis of the date of export, is limited to cases where the taxpayer cannot or does not provide reliable evidence as to the actual or appropriate pricing date.

Association was particularly prominent in the BEPS era, when lower-income countries had little formal say at the OECD. While several policy decisions from this era are cited as addressing the concerns of lower-income countries, all resulted mainly from the preferences of OECD members or large emerging economies. The sixth method is perhaps the most illustrative case (see Box 1), although it also applies to mandatory binding arbitration, country-by-country reporting, hard-to-value intangibles and the Unified Approach. Interviewees said the push for formalisation of the sixth method in the TPGs was spearheaded by Latin American countries that already had it in their legislation, especially Argentina, with support from other emerging economies favourable to simplifying transfer pricing methods. 'The push mainly came from the BRICS... those were the countries that really had a lot of say', said one interviewee (lower-income country), although staff from the ATAF secretariat also explained that they had supported an alliance among resource-rich countries.

Although considerable diplomatic effort was expended to work out a compromise, uptake of the OECD version has been limited so far, although it has been incorporated into ATAF's Suggested Approach to Transfer Pricing Legislation, and Argentina has repealed its sixth method and reformed domestic legislation to align with the OECD outcome (Malla and Godoy 2019). It has yet to filter down into the legislation of lower-income countries. 
Using public market prices as reference points for pricing commodity transactions is, however, already prevalent in Africa, although it rarely appears in legislation. As one African interviewee explained: 'Most African countries use that as a cross-check, after using the [transfer pricing] analysis. Checking what they get, to create that level of satisfaction' (lowerincome country). As such, our interviewees described the inclusion of the sixth method in the OECD Guidelines as a 'win' because it was an endorsement of this prevalent practice:

The big success is just recognition by the OECD of the sixth method. Whether they put it as a subsidiary method, the fact that it's recognised, it brings it to the fore... When you're dealing with taxpayers and the like it helps that something is recognised. (Lower-income country)

The significance of recognition by the OECD in a sense is that it reduces disputes in interpretation and also it reduces the extent to which the EU and formations like these would accuse Africa of acting unilaterally.

(Regional tax organisation)

Association is likely to remain a prominent dynamic that helps to move global tax standards in the direction of lower-income country preferences in the short term, especially as they catch up to G20 and OECD countries in technical standard-setting participation (see Section 3.1). They may do well by identifying ways in which they can benefit from changes brought about by OECD or, especially, emerging market G20 countries. However, long-term reliance on association leaves lower-income countries vulnerable to changes in emerging economies' preferences, e.g. China has begun departing from its historical alignment with lower-income countries in global tax discussions (Christensen and Hearson 2021; Hearson and Prichard 2018).

\subsection{Anticipation}

Conscious of limited participation by lower-income countries, officials in international organisation secretariats - and some from other countries or from civil society - anticipate and advocate policies to benefit lower-income countries, without the latter actively pushing their preferences. OECD policymaking is already premised on anticipation: several interviewees with secretariat experience referred to the power and responsibility that comes because it 'holds the pen'. Anticipation rarely occurs in isolation from the other mechanisms discussed, but is often necessary for success, acting as the trigger or driving force. The quality of anticipation and the combination with other mechanisms is critical to how relevant a new measure will be to lower-income countries.

Anticipation frequently entails forming a view about what is in lower-income countries' interests, not merely the positions they may take. It requires familiarity with lower-income country contexts, which many interviewees felt was a challenge at the IF given the gulf between the realities of tax administration in OECD and lower-income countries. Some felt that the situation was improving. Secretariat staff and OECD-country delegates are interacting more with those from lower-income countries, both at the IF and in other situations, e.g. tax treaty or competent authority negotiations:

Jointly working cases and exchanging views, you build up capacity and you really get insights into what's important for [lower-income countries] in terms of policy and what failures are there of the current international tax system. There are lots of things you can glean from those interactions compared to a two-minute intervention at the IF meeting. (OECD country) 
At least people are realising now that things are not the same... I recall at one meeting when I told them the number of tax auditors we have in one country and somebody said 'oh that is less than we have in one small office'. I believe we have started a process but I can tell you we are not yet there. (Lower-income country)

To illustrate the importance of good anticipation, we compare two cases that both began with anticipation: country-by-county reporting (CBCR) and technical service fees (Article 12A). The former produced an outcome that has not been widely adopted by lower-income countries, while the latter has had a transformative impact on negotiating practices.

\section{Box 2 Country-by-country reporting}

Championed by civil society activists, CBCR entails an expansion of corporate financial reporting breaking down key financial information by jurisdiction. It was adopted by the UK government during its G7 presidency in 2013 and brought onto the BEPS agenda as a risk assessment tool for tax administrations. Three aspects were raised by interviewees from lower-income countries as problematic: (1) Rather than creating a regime based on the publication of CBCR reports or on MNEs filing them in each country in which they operate, the BEPS minimum standard requires filing only in the home country. Other countries can only access the new reports if a treaty is in place and under strict confidentiality safeguards. (2) Information in CBCR reports omits key data on related party transactions within the MNE that would increase its usefulness for identifying potential profit shifting. (3) Only MNEs with a turnover of $€ 750$ million or above are obliged to report, ruling out many MNEs of interest to lower-income countries. Uptake among lower-income countries has been low, and five years after CBCR was adopted by the G20 and OECD, only one lower-income country - Pakistan has any active exchange relationships allowing it to receive country-by-country reports. ${ }^{15}$

CBCR was described both as 'the one big win that came out of the BEPS project' by a former official from an emerging market country, and 'a big failure' by a lower-income country official. Proponents correctly foresaw that comprehensive coverage and an accessible data delivery mechanism would be critical to making CBCR useful. However, governments of large OECD countries - including the UK - as well as businesses, advocated strongly for limiting access to the new CBCR data (Christensen 2020):

There were developing country positions that wanted to have more information. (...) But a lot of that discussion was made difficult by the argument that this information was sensitive. (OECD country).

There was little active mobilisation for the proposal among lower-income countries but its advocates emphasised its potential benefits. Once on the agenda, it was embraced by nonOECD G20 members, who sought unsuccessfully to expand the proposal beyond what was supported by core OECD members. ATAF became involved but had limited routes to influence (Burow 2014). Our interviews revealed that there is now widespread enthusiasm for the concept among lower-income country revenue authorities, combined with some frustration with the design of the rules. The implementation requirements are regarded as onerous, especially when compared to the limited utility of the data:

We have put in place a large amount of resources which have all been for nothing. If the... tax administration had completed its legal framework by signing competent authority agreements, and if it had finalised the configuration of its exchange platform, it could have received CBCR from foreign jurisdictions. But such declarations would...

15 OECD 'Country-by-Country reporting exchange relationships', September 2020, www.oecd.org/tax/beps/country-bycountry-exchange-relationships.htm 
not contain information sufficiently detailed to guide tax audits. Due to this, and the costs of complying with the standard, CBCR is, at this stage, of limited interest to [our] tax administration. However, since it is the subject of a minimum standard to which [we are] committed, steps are being taken to implement it.

(Lower-income country)

CBCR can be seen as a missed opportunity, a reform based largely on anticipation that is seen as problematic or irrelevant by most lower-income countries. As one interviewee said, 'This is why, now, still we are not in a position to say how much African countries have benefitted from this' (lower-income country). This sense of disaffection means that there has not been a concerted effort by lower-income countries to push for major changes to the CBCR standard during a 2020 review.

\section{Box 3 Technical services fees (UN Tax Committee)}

In 2014, the UN Tax Committee agreed to include a new article, 12A, in the next update to its Model Double Taxation Convention between Developed and Developing Countries, published in 2017. The article provides source states - particularly lower-income countries with the right to tax fees for technical services paid outward from a company in the source state. Although inclusion of such an article in tax treaties had been policy for many lowerincome countries for years, its adoption onto the UN Model was contentious within the committee. Most members from OECD countries opposed it, and the final decision rested on a knife-edge majority vote. Uptake has been rapid: since 2017, technical service fees clauses have been included in more than half of tax treaties signed by lower-income countries, compared with around a third in the ten years beforehand. ${ }^{16}$

The technical service fees case provides a more successful example of anticipation. Work on Article 12A was spearheaded by a committee member from an OECD country, with critical technical input from a Canadian adviser and early support from the committee's Indian member. It would not have passed without the vocal support of a few OECD-country experts and the UN secretariat. Lower-income country members supported it, but sometimes seemed a silent majority:

The subcommittee was led by an OECD member, who had developing country interests at heart... She was focused on getting an article through. That helped strengthen the hands of developing countries. (Lower-income country)

I was also actively and strongly supporting the introduction of the $12 \mathrm{~A}$, and I was very frustrated... [at] how that work was obstructed by US and UK delegates and other OECD country delegates. (OECD country)

Members from developing countries, although not vocal, when it mattered, when you took a vote, they were present. (International organisation)

This latent support from lower-income countries reflects a key difference between CBCR and $12 \mathrm{~A}$, both controversial reforms marked by anticipation. CBCR emerged from a top-down discussion, and lower-income countries had no experience of using it. In contrast, Article 12A was based on the experiences and preferences of lower-income countries, often included in their existing treaty practice as well as in their domestic laws. Those leading the 12A work could anticipate confidently because they had an existing policy template. A coalition of lower-income countries could also be mobilised more easily because committee members from lower-income countries had personal experience and national negotiating positions on

16 Tax Treaties Explorer, http://treaties.tax 
which to draw. The committee member from Senegal, for example, submitted a paper on $12 \mathrm{~A}$ drawing on his country's negotiating experience. And Committee members from African countries drew on their experience during crucial discussions: 'There were various arguments that $[12 \mathrm{~A}]$ was too wide, it was too confusing. But there were some developing countries who have it in their treaties [like us], it was a red line for us' (lower-income country).

Comparing $12 \mathrm{~A}$ and $\mathrm{CBCR}$ sheds light on different structures of decision making. Although the compositions of the UN Tax Committee and the Steering Group are broadly similar, the likelihood that an outcome at the UN might resemble the practices and preferences of lowerincome countries is higher, because there is no requirement to reach a consensus. At the IF, the consensus requirement means that proposals anticipating lower-income countries' interests are likely to be watered down: 'The view is that the OECD secretariat is listening to developing countries, but the big countries are not, and are ploughing on regardless', said one interviewee (international organisation). The drawback of majority decision making is that powerful countries cannot be compelled to abide by a decision with which they disagree.

Anticipation has clear potential as lower-income countries become more integrated into global tax standard setting. Yet, like association, it leaves much discretion in the hands of powerful, central actors, often large OECD economies and key bureaucrats. This means that decisions can often merely replicate the existing top-down power structure. Doing anticipation well means embedding it in a bottom-up approach, drawing from the existing experience of lower-income countries. If combined with collaboration or individual authority, anticipation may be more effective, as illustrated by the contrasting outcomes of CBCR and $12 \mathrm{~A}$.

\subsection{Collaboration}

Collaboration is the mechanism most obviously implied when communications about the IF emphasise its 137 members. If lower-income countries work together, and with other countries with common interests, they should draw considerable influence from combined economic size and diplomatic force. But coalition working requires the mobilisation of diplomatic resources to form and advance a unified position. Although a coalition may include large G20 members as well as small lower-income countries, we distinguish collaboration from association in the sense that it entails lower-income countries' active involvement in formulating positions, rather than spillover benefits from positions formed by more powerful countries.

Collaboration is familiar in other areas of global economic governance, such as trade (Lee 2009; Narlikar and Tussie 2004). The WTO Doha round negotiations were characterised by a shifting terrain of interest-based coalitions among lower-income countries, allowing them to form narrow issue-specific coalitions and pool their negotiating capacity (Hopewell, 2015). Similarly, the G24 was created to help lower-income countries organise around IMF deliberations, and the G77 for the UN. We can think of coalitions on a spectrum between two idea types: longstanding blocs based on broad geographic, cultural or other bases, and temporary issue-based alliances. Narlikar and Tussie argue that in trade negotiations, the most effective coalitions have combined attributes of both: pragmatic cohesion and expertise focused around a single purpose, but also a normative foundation and a capacity to learn.

The outstanding vehicles for collaboration in the IF have been the G24 and ATAF. Other organisations mentioned by interviewees were the South Centre, CIAT, SGATAR and CREDAF. But unlike the G24 and ATAF, they have not organised and led key policy interventions. ATAF stands out for its leadership role in most of our IF-era cases, and our discussion consequently has an African focus. As for the G24, the SEP case represented its first foray into the IF. 


\section{Box 4 Significant Economic Presence}

Under the Inclusive Framework's Pillar One work on digital taxation, the most ambitious input involving lower-income countries was the SEP proposal submitted by the G24, one of three proposals from IF members for reallocating taxing rights circulating within the IF in 2018. It proposed that a company would have a taxable nexus in a country in the absence of a physical presence if a critical mass of certain factors were present, including revenue from sales of goods and services effected through digital means, user base and associated data input, and volume of digital content. Profits would be allocated to that country on a formulary basis using four factors: sales, assets, employees and users. The OECD secretariat eventually drafted a 'Unified Approach' to break a tough negotiating deadlock, and this became the focus of negotiations from late 2019. Neither G24 delegates nor OECD secretariat officials whom we interviewed felt that there were technical elements in the Unified Approach specifically based on the SEP proposal as opposed to other proposals. ${ }^{17}$

Although new to global tax standard setting, the G24 benefits from political backing, directly drawing from high-level diplomats in ministries of foreign affairs and finance. These individuals do not represent their countries in the IF and it was initially challenging for the G24 to build a network of the right country delegates for tax negotiations. It spans large emerging markets with extensive capacity, e.g. Brazil and India, and lower-income countries, e.g. Nigeria, Ghana and Gabon. Inevitably, some members are more involved in the formulation of joint positions than others. According to an OECD secretariat official, 'some senior officials from the G24 have distanced themselves from the block view submissions, seeing the dangers of a block mentality damaging the chances of consensus and because of the varied interests of countries in established groupings' (Dickinson 2019). In frank terms, the G24 is sometimes portrayed as a vehicle for Indian positions, and India's leading role in the G24 has been integral to its success. As one interviewee, involved in both the $\mathrm{G} 24$ and other collaborations, said, 'where the [G24] comments have seemed to conflict with [IF] positions, there has been a reluctance to upset India, which takes a leading role in G24 tax issues, and so the G24 has had a hearing mainly because of the membership' (lower-income country). The initial drafting of the SEP proposal was led by India and Colombia and based in part on Indian domestic law. Nonetheless, our interview sample included officials from seven G24 member states, and we observed widespread collective ownership:

This would not have made the ministerial meeting or our communiqué if India hadn't been the chair [but] no one in the group thinks this is an India proposal, that this is really India. (International organisation)

I cannot lay claim to any personal idea, what I can say is that we agree with the concept, we understand the concept even though it is difficult for people from the developed world to accept, we see it as simpler and a lot easier to implement... SEP the principle, the idea is from the G24 and there are contributions from everyone. (Lower-income country)

The G24's collaboration through the IF Steering Group is particularly important: here, the G24 had seven members represented during 2020.

It has been very helpful that they can go to the [Steering Group] meetings representing their countries, but they know that there are shared views there. That

'Amount B' is the component within the Unified Approach in which lower-income countries have expressed most interest, but it is not based on a proposal from lower-income countries: it is an example of anticipation by the OECD secretariat. It 'simply would not have been there without developing country influence' according to one person involved in the drafting process. 
matters a lot. They come in stronger, to some degree... Because they had a collective view, that was what got some of the views into the discussion.

(International organisation)

Although the SEP proposal made waves, one G24 representative described the Unified Approach as 'very far away from what I would call a victory for the G24 or developing countries' (other country). Rather, its impact was more noticeable in its effect on institutional procedures and norms, signalling the arrival of a new powerful alliance in and around the G24 whose interests had to be anticipated (Athanasiou 2019). As the same official explained:

Bring[ing] together some of the developing world countries in one single bloc definitely made it worthwhile for the secretariat to make sure that we were also on board before putting forward some of the decisions, or at least knowing some of what the issues would be... So I think one of the victories is that you now get these calls, you get these papers [ahead of time].' (Other country)

ATAF, in contrast, relies less on political support and engagement, and more on technical interventions. ${ }^{18}$ ATAF members and secretariat are active at working party and Steering Group level. ATAF participates through a collaboration of country representatives and observers, the latter including secretariat staff and members from non-IF countries. Many interviewees noted that the perception of an African bloc gives African countries a stronger voice than other lower-income countries:

I think it would be safe to say - and this is not pejorative in any way - that a more influential developing country or persons from the African continent, their views would naturally hold more sway if decisions are ultimately to be made. And we fully understand that, because you're looking at a bloc of countries. (Other country)

ATAF's key resource is technical collaboration, which allows African states to overcome their individual capacity constraints. Many interviewees said there was a broad respect for African interventions in Working Party 6 on transfer pricing especially. One element of this is the presence of ATAF secretariat staff to 'backbench' country delegates to articulate positions. Another is the Cross-Border Taxation Technical Committee (CBT), formed in 2015. It meets before key working party and Steering Group meetings and has published a series of technical notes on digitalisation.

We send these people to the IF to be involved in really high-level but also technical discussions, and the problem is that they really don't know what they think. So, it's also about helping these countries work out what they want. And that's one of the things that ATAF has been good at. (Regional tax organisation)

I think that ATAF also have played an important role. I've seen it more in the face-toface meetings. (...) ATAF were very good when it was in the face-to-face, they will still make contributions now, but it helped there that you could talk in the coffee break. They were very much listened to. (OECD country)

The G24 and ATAF illustrate that collaboration can empower lower-income countries with little to no influence capacity on their own. This includes countries who are not even formally members of the IF: both ATAF and G24 includes non-IF members, whose national experts have played a key role in developing and promoting policy positions at the IF through these organisations. In contrast to conventional wisdom that '[s]mall states can shape outcomes,

18 ATAF is seeking to remedy the lack of high-level political support by calling on mobilisation by, in particular, the African Union (African Union (2020) 'Outcome Statement $-4^{\text {th }}$ High Level Policy Dialogue', 27 August, https://au.int/en/pressreleases/20200827/outcome-statement-4th-high-level-policy-dialogue). 
but only if they sit at the negotiating table' (Brazys 2014: 648), our IF cases illustrate that influence can happen despite no formal seat. As an official from a non-IF member G24 country said, the G24's value was in 'getting our views into the IF, and being aware of what's going on there all the time, without being members' (lower-income country).

\subsection{Individual authority}

While economic strength, alone or through collaboration, is an inescapable factor determining delegates' influence on international tax policy, their personal qualities and reputations also determine how much sway they have over policy decisions (Christensen 2020; Picciotto 2015; Seabrooke and Wigan 2016). Individual authority covers instances where key individuals from lower-income countries develop and push a specific policy position successfully based on recognised personal skills and authority. Technical expertise and interpersonal relationships are frequently the glue that holds together collaborations, and an enabling factor for good anticipation.

Across global governance, the experience, professionalism and socialisation of skilled individuals can enable lower-income countries to effectively penetrate technical policymaking in international organisations (Apecu 2013). By investing in their experts, countries can actively cultivate this form of influence, which has demonstrably enabled effective representations of their interests in global governance institutions (Eskelinen and Ylönen 2017; Shaffer, Sanchez and Rosenberg 2008).

Several aspects of IF decision making make this dynamic especially important. Steering Group membership is in a personal capacity. Individuals with reputations for technical and diplomatic competence are sought out by secretariats: several delegates from lower-income countries observed that, after speaking authoritatively at the OECD, they were invited to take on committee roles. The anticipatory nature of secretariat-led negotiations creates a need for a smaller, trusted 'inner circle', consulted before proposals are sent to the broader membership. Secretariat members try to identify key delegates to qualify proposals and head off objections, as an OECD secretariat member explained:

The real thing in our process is, who gets to shape the papers... [In one typical example, after the secretariat had an idea] the first three phone calls we made were US, India, Nigeria. The US are technically always good, they provide the very best people. But [the Indian and Nigerian delegates], because they're smart, you can have a real conversation there. That's where you have the influence.

(International organisation)

Authoritative individuals can also gain recognition through leadership within a broader constituency. Notably, Nigeria does so within ATAF and the G24, and India within the G24. For lower-income countries, a particularly effective strategy is using such groupings to pool expertise and build the profile of capable experts representing the broader constituency. ATAF did this in respect of the Authorized OECD Approach, relying on trusted, experienced lower-income country representatives, who had built up experience and reputations in WP6. 


\section{Box 5 Authorized OECD Approach}

Work spilling over from BEPS Action 7 was to provide additional guidance on profit attribution to a permanent establishment (PE). The AOA, contained in the 2010 update to the OECD Model Tax Convention, is seen as a shift of taxing rights away from source countries, because it introduces arm's length transfer pricing into the relationship between a PE and its parent company. Not all countries -- in the OECD as well as outside endorse the AOA principles in their tax treaties or domestic legal arrangements. On the insistence of WP6 participants, in particular ATAF representatives, the final document emphasised that the guidance did not intend to 'extend the application of the authorized OECD approach to countries that have not adopted that approach', and stressed that PE profit attribution 'in any particular case will be governed by the applicable tax treaty' (OECD 2018).

African participants in the AOA discussions explained that their concerns had been repeatedly overlooked, even though they were shared more widely. Yet it was ATAF's experts who effectively intervened to insist on a change of language:

On the day the document was to be passed we raised those issues and the discussion had to be suspended. (...) We were able to listen to the other side and they were able to listen to us and we were able to come back and in the TPGs we have, yes the OECD approach, but yes other methods that are also in use across the world. (Lower-income country)

One of the countries that came up to me afterwards was a smaller developed country; and they came up at the end and said they'd raised it originally at a previous [WP6], and it was completely rejected, and they didn't agree with the rejection but they felt they were outnumbered, and they had given up. So they were happy that ATAF had persevered. (International organisation)

These language changes represent influences on substantive policy. Some interviewees characterised them as relatively minor, and the AOA intervention was largely defensive, with African countries perhaps emboldened to intervene to preserve their existing policy space. However, as with Article 12A, this intervention provides lower-income countries with a stronger platform to argue for their policy preferences.

[G]uidance produced by the OECD is increasingly being viewed (...) as the standard to be applied in all countries around the world. It is therefore crucial that ATAF has achieved this outcome of ensuring the new guidance reflects the different approaches countries use on attribution of profits. This gives the guidance broader acceptance among tax jurisdictions around the world, including in Africa. So it is a positive outcome for both ATAF and OECD members. (Lower-income country, cited in ATAF 2018)

The same few names - several of whom we interviewed - were mentioned by many IF participants as effective delegates across the case studies we examined. One was described as '[having] the right skills and I've been impressed with his interventions' (OECD country). On another: 'She's excellent, and if you have someone like that who knows the subject matter and can put forward relevant good arguments, they can move people, they can move the process' (OECD country).

Two important aspects of socialisation are perhaps underappreciated: a long involvement in global tax negotiations, and a presence in transnational settings outside the IF itself, including academic settings such as the International Fiscal Association (IFA) and certain 
universities, and international organisations. Both allow delegates to develop networks of contacts and a general familiarity with how the international tax community conducts itself. 'Imagine the difficulty coming across people who have spent their whole lifetime in the international tax system', said one interviewee. 'People from smaller developing countries, they just don't have that. It's quite difficult to do that catch-up. You can understand how people are completely overwhelmed by the confidence being projected there' (international organisation). As two interviewees, cited by others as authoritative experts but no longer in government roles, described:

I've developed relationships with most of the especially African country delegates, and that relationship has continued beyond the conferences we've attended. And that helps... in terms of the fact that you know some of the positions of the counterparts, even if they are not present, you are able to speak on issues because you know what other African countries are thinking. Sometimes when I speak at the UN, and I mention developing country experiences, I am actually articulating what I have discussed with my colleagues who are not members of the committee. (Lower-income country)

Strengthening the relationships outside of the [WP 6] meetings was a huge influential factor. I had many times we would have informal discussions, they would say 'there's no way we can agree with you in the room, because we have a certain country position, but definitely we understand what you're saying'. As you get familiar and you forge these personal relationships you get to see how things really are. Also you get to realise you have to have strong voices at the table. I saw it in my own journey at WP6. I started off being very observant, trying to understand my place in the room. I said to the secretariat, I think WP6 is a very daunting place to be.

(Non-OECD G20 country)

While effective given the right personnel and negotiating context, individual authority mechanisms are fragile, because authoritative individuals with deep technical knowledge, good networks, and experience are in short supply. The difficulties are familiar: people are moved around within the civil service, promoted out of negotiating positions, not given the political support or the time to participate, or move to the private sector (or indeed to international organisations). As one interviewee said, 'You have the curse that if you are good, you have good English, you will be snatched by the private sector... I see a number of good delegates from African countries, I'm not sure if they're gonna be there in five years' (international organisation). This thread runs through our interviews: helping individuals to reach such a point, keeping them in government roles, and maintaining them as consistent representatives will be a hugely significant determinant of lower-income countries' effective participation at the IF and the UN Tax Committee.

\section{Conclusions and recommendations}

This paper maps and evaluates lower-income country participation in global tax standard setting between 2012 and 2019, focusing on seven significant IF policy decisions, and one at the UN. Structural obstacles to participation, including limitations on expert capacity, lack of political support, and the absence of effective coalitions, are exacerbated by OECD/IFspecific ways of working, e.g. 'brutal' or choreographed meeting environments, and high participation costs. Some small gains have been secured, and those involved are optimistic about incremental progress:

If you look at a 600-page document, which is what the TPGs are, and you manage to change six paragraphs... You can't think to change something overnight, you have to 
keep chipping away, and the real success is when we finally break out. That takes a long time, and that requires cultural change. (Regional tax organisation)

Limited success is partly due to reliance on the mechanisms of anticipation and association, in which lower-income countries are more passive, with few successes involving the more active collaboration and individual authority mechanisms.

To understand why, it is important to consider the constraints created by the IF's history and institutional design. Many countries join for help aligning domestic rules with international standards, or because of coercive pressure, not primarily to participate in standard-setting. The IF's minimum standards distract countries' limited capacity away from new negotiations and deter some from joining altogether. There is also a self-reinforcing perception among many that the negotiating agenda, timescale and outcomes are dominated by OECD and G20 states, leading to an acquiescent 'wait and see' attitude. Finally, the pursuit of global consensus naturally leads to incremental and complex outcomes, reducing the incentive to invest in negotiations. The great strength of such consensus, though, is that IF members can usually count on OECD countries to implement the agreement.

Difficulties with the IF could reinforce calls for a UN committee at intergovernmental level, yet lower-income countries would face many of the same obstacles there. Technical work will continue to be the preserve of expert groups. In terms of coalitions, a much more diverse ecosystem of short-term alliances and long-term bloc formations will be needed, but will take time to form: achieving truly inclusive global tax governance institutions will take decades. In the meantime, a pragmatic approach entails asking which of lower-income countries' priorities from international cooperation can be achieved through the IF, and which require a different type of institution. We offer practical suggestions focusing on the IF as it stands.

\section{Individual authority: addressing structural obstacles}

There is no substitute for investment in people. Adequately resourcing lower-income countries' participation is key, and must go beyond direct travel costs to include the opportunity costs of significant time commitment by skilled technicians. A long-term perspective is needed to build a cohort of people with deep knowledge, experience and networks, and retain them in civil service positions where this experience can be channelled into country representation. Key to making this work is achieving a critical mass of active intervention by a representative group of delegates from lower-income countries, rather than boosting raw numbers of members.

- Donors could support the creation of an International Tax Participation Fund, independent of international and regional organisations, but working with their secretariats. This would complement existing provision by targeting its resources to support a limited cohort to become elite negotiators, and by emphasising diplomatic as well as technical skills. ${ }^{19}$ It would identify countries and individuals to take leadership roles in lower-income country networks, with careful distribution of awards regarding geography, language and income. It could provide resources directly to revenue administrations and/or finance ministries to compensate for direct and indirect participation costs, in return for a commitment to consistent representation and to building common positions. It could also provide a mentorship scheme, and funding for academic study and secondments.

- The governments of lower-income countries should recognise that there is no substitute for investment in skilled and experienced representatives. This includes keeping senior staff in negotiating roles in post for longer periods, with proper succession planning; hiring negotiators with diverse experience; ensuring staff heading towards senior

\footnotetext{
19 The NGO 'Independent Diplomat' may provide a model for the latter.
} 
negotiating roles can access placements in international organisations and masters-level study; ensuring that delegates can adequately prepare for and participate in negotiations. Countries without the depth of international tax staff for such a programme may be better served by feeding into the deliberations of regional bodies rather than participating directly.

\section{Collaboration: building platforms from the ground up}

Coalitions appear to be most energetic when united around proposals that come from lowerincome countries. If they use countries' existing practices as a template, such proposals have a technical grounding, political leverage, and a base from which negotiating partners can read lower-income country preferences. Indeed, most of the successful cases we identified entailed the defence of pre-existing positions or the dissemination of current practice. Strengthening collaboration at the IF might therefore begin outside it:

- Lower-income countries, regional organisations and donors should focus more on SouthSouth collaboration to design domestic/regional reforms based on their own experiences, rather than on OECD/G20 policy agendas. This could lead to proposals suitable for consideration by the IF. On the digitalisation agenda, for example, lower-income countries may benefit most by learning from each other's experiences with e.g. digital services taxes, economic presence rules, VAT rules for e-commerce, and alternative minimum taxes.

- With donor support, countries should enhance collaboration by building issue-specific dialogue among and between ATAF, CREDAF, CIAT, G24, G77, SGATAR, South Centre and other coalitions involving lower-income countries, and with other stakeholders where interests overlap. This could include organising pre-, side- and post-meetings around international negotiations. Cooperation between these organisations, in the immediate term between the G24, ATAF and South Centre, could lead to fertile and powerful collaboration and help bridge the gap between technical and political engagement with international tax negotiations.

\section{Making a more inclusive framework}

Our research highlighted some challenges inherent to the IF's way of working, but there are steps that the IF, the OECD secretariat, and other organisations could take to adapt to the reality for lower-income countries.

- The volume, complexity and pace of IF negotiations are unlikely to ever be appropriate to the capacity of most lower-income countries. The Steering Group could assist by identifying high priority areas for them. In these areas, the secretariat should produce summary briefs, and ensure translation of written documents and of all relevant meetings. A timeline realistic for resource-constrained contexts should be adopted for these areas, with greater use of virtual meetings.

- Interventions such as inductions and pre-meetings should be timed and targeted to support policy analysis, the formation of positions backed by capitals, and alliance building - not simply to get delegates up to speed on the eve of a plenary. ATAF's practice of holding CBT meetings prior to key working party meetings seems a good model. Another possibility is 'post-meetings' reflecting on decisions taken and how to move forward.

- New IF delegates should receive comprehensive inductions incorporating 'unwritten rules' and negotiation training. A mentorship, buddy or shadowing scheme is also needed. Some such efforts have been made by the OECD secretariat, but a South-South skill-sharing approach may improve uptake and impact.

- To manage expectations and build trust, communication about lower-income countries' involvement in and gains from IF standard setting needs to move beyond '137 countries 
on an equal footing'. The most recent IF progress report is a positive step (Inclusive Framework 2020). We propose two reforms. First, the IF should formalise and publicise aims, supported by actionable initiatives and transparent reporting, for diverse expert representation in technical policymaking beyond the IF plenary. Second, the successful design of IF instruments to meet lower-income countries' needs should be monitored by their uptake in practice, rather than high-level claims about their potential.

- The limitations of the consensus model have already led the OECD to follow a 'minilateral' approach when it delivered a mandatory binding arbitration solution for only those countries choosing to opt in. This model could create flexibility to move beyond the lowest common denominator approach, and aid the prioritisation of limited capacity. A first step could be to reconsider the universality of the minimum standards. 


\section{References}

Adler, E. and Pouliot, V. (eds.) (2011) International Practices, Cambridge University Press

Apecu, J. (2013) 'The Level of African Engagement at the World Trade Organization from 1995 to 2010', International Development Policy 4.2: 29-67

ATAF (2019) The Place of Africa in the Shift Towards Global Tax Governance: Can the Taxation of the Digitalised Economy Be an Opportunity for More Inclusiveness? Pretoria: ATAF

ATAF (2018) Resolving African Challenges in Transfer Pricing, Medium, https://medium.com/african-tax-administration-forum/resolving-african-challenges-intransfer-pricing-44868cfacb64

Athanasiou, A. (2019) 'Developing Countries Key to Digital Tax Consensus', Tax Notes International, 20 May, https://www.taxnotes.com/tax-notes-international/digitaleconomy/developing-countries-key-digital-taxconsensus/2019/05/20/29h74?highlight=\%22user\%20participation $\% 22$

Aukonobera, F. (2012) 'Uganda', in M. Lang, P. Pistone, J. Schuch and C. Staringer (eds.), The Impact of the OECD and UN Model Conventions on Bilateral Tax Treaties, Cambridge University Press: 1083-1100

Bayne, N. and Woolcock, S. (eds.) (2011) The New Economic Diplomacy: Decision-making and Negotiation in International Economic Relations, 3rd ed., rev. updated, Aldershot: Ashgate

Brazys, S. (2014) 'Outside Looking In: Non-accession to the WTO', Cambridge Review of International Affairs 27.4: 644-665

Brooks, K., and Krever, R. (2015) 'The Troubling Role of Tax Treaties', in G. M. M. Michielse and V. Thuronyi (eds.), Tax Design Issues Worldwide, Alphen aan den Rijn: Kluwer Law International: 159-178

Burow, M. (2014) 'Developing Countries Seek Voice on BEPS Treaty Proposals', Tax Notes International, 14 April, https://www.taxnotes.com/tax-notesinternational/treaties/developing-countries-seek-voice-beps-treatyproposals/2014/04/14/sjyf?highlight=\%22Action $\% 2013 \% 22 \% 20 \% 22$ developing $\% 20$ cou ntries $\% 22$

Checkel, J. T. (2005) 'International Institutions and Socialization in Europe: Introduction and Framework', International Organization 59.4: 801-826

Christensen, R. C. (2020) 'Elite Professionals in Transnational Tax Governance', Global Networks

Christensen, R. C. and Hearson, M. (2019) 'The New Politics of Global Tax Governance: Taking Stock a Decade After the Financial Crisis', Review of International Political Economy 26.5: 1068-1088 
Christensen, R. C. and Hearson, M. (2021) 'The Rise of China and Contestation in Global Tax Governance', Asia Pacific Business Review

Christians, A. (2010) 'Taxation in a Time of Crisis: Policy Leadership from the OECD to the G20', Northwestern Journal of Law and Social Policy 5.1

Christians, A. and van Apeldoorn, L. (2018a) 'Taxing Income Where Value Is Created', Florida Tax Review 22.1: 1-39

Christians, A. and van Apeldoorn, L. (2018b) The OECD Inclusive Framework', Bulletin for International Taxation, April/May 2018

Clarke, V., Braun, V. and Hayfield, N. (2007) 'Thematic Analysis', in J. A. Smith (ed.), Qualitative Psychology: A Practical Guide to Research Methods, 2nd ed., SAGE Publications Ltd

Collin, M. (2020) Does the Threat of Being Blacklisted Change Behavior? Regression Discontinuity Evidence from the EU's Tax Haven Listing Process, Global Economy and Development Working Papers 139, Brookings

Dickinson, B. (2019) 'The Inclusive Framework is Considering Radical Proposals, but in the Real World...', International Centre for Tax and Development (ICTD) blog, 18 November, https://www.ictd.ac/blog/oecd-inclusive-framework-tax-proposalsnegotiation/

Durst, M. C. (2019) Taxing Multinational Business in Lower-Income Countries: Economics, Politics and Social Responsibility, Brighton: Institute of Development Studies

Economic and Social Council (2004) Committee of Experts on International Cooperation in Tax Matters, ECOSOC Resolution 2004/69

Eskelinen, T. and Ylönen, M. (2017) 'Panama and the WTO: New Constitutionalism of Trade Policy and Global Tax Governance', Review of International Political Economy 24.4: 629-656

Eyitayo-Oyesode, O. A. (2020) 'Source-Based Taxing Rights from the OECD to the UN Model Conventions: Unavailing Efforts and an Argument for Reform', Law and Development Review 13.1: 193-227

G20 (2015) G20 Leaders Communiqué, Antalya, 16 November, http://www.g20.utoronto.ca/2015/151116-communique.html

Hearson, M. (2021) Imposing Standards: The North-South Dimension to Global Tax Politics, Cornell University Press

Hearson, M. (2016) Measuring Tax Treaty Negotiation Outcomes: The ActionAid Tax Treaties Dataset, ICTD Working Paper 47, Brighton: Institute of Development Studies

Hearson, M. and Prichard, W. (2018) 'China's Challenge to International Tax Rules and the Implications for Global Economic Governance', International Affairs 94.6: 1287-1307

Heydon, K. (2011) 'The OECD: Lessons from Investment and Services', in N. Bayne and S. Woolcock (eds.), The New Economic Diplomacy: Decision-making and Negotiation in International Economic Relations, 3rd ed., rev. updated, Aldershot: Ashgate: 231-248 
Hopewell, K. (2015) 'Different Paths to Power: The Rise of Brazil, India and China at the World Trade Organization', Review of International Political Economy 22.2: 311-338

Inclusive Framework (2020) OECD/G20 Inclusive Framework on BEPS: Progress Report July 2019-July 2020, Paris: OECD Publishing

Jogarajan, S. (2018) Double Taxation and the League of Nations, Cambridge University Press

Johnston, A. I. (2008) Social States: China in International Institutions, 1980-2000, Princeton University Press

Kahler, M. and Odell, J. (1989) 'Developing Country Coalition-Building and International Trade Negotiations', in J. Whalley (ed.) Developing Countries and the Global Trading System, Palgrave Macmillan UK: 149-167

Lee, D. (2009) 'Bringing an Elephant into the Room: Small African State Diplomacy in the WTO', in A. F. Cooper and T. M. Shaw (eds.), The Diplomacies of Small States: Between Vulnerability and Resilience, Palgrave Macmillan UK: 195-206

Lesage, D., McNair, D. and Vermeiren, M. (2010) 'From Monterrey to Doha: Taxation and Financing for Development', Development Policy Review 28.2:155-172

Malla, M. G. and Godoy, P. (2019) 'INSIGHT: Argentina Updates its Transfer Pricing Rules', Bloomberg Tax, 15 July, https://news.bloombergtax.com/transfer-pricing/insightargentina-updates-its-transfer-pricing-rules

Marcussen, M. (2001) 'The OECD in Search of a Role: Playing the Ideas Game', European Consortium for Political Research, 29th Joint Session of Workshops, Grenoble, 6-11 April 2001

Mason, R. (2020) 'The Transformation of International Tax', American Journal of International Law, 114.3: 353-402

Michalopoulos, C. (1999) 'The Developing Countries in the WTO', The World Economy 22.1: 117-143

Mminele, M. (2015) Statement on Behalf of the Group of 77 and China by Mr Mahlatse Mminele, Deputy Permanent Representative of the Republic of South Africa to the United Nations, at the Special Meeting of the Economic and Social Council (ECOSOC) on International Cooperation in Tax Matters, 22 April, https://www.g77.org/statement/getstatement.php?id=150422b

Mutava, C. N. (2019) Review of Tax Treaty Practices and Policy Framework in Africa, ICTD Working Paper 102, Brighton: Institute of Development Studies

Narlikar, A. (2010) 'New Powers in the Club: The Challenges of Global Trade Governance', International Affairs 86.3: 717-728

Narlikar, A. (2003) International Trade and Developing Countries: Bargaining Coalitions in the GATT \& WTO, Taylor \& Francis

Narlikar, A. and Tussie, D. (2004) 'The G20 at the Cancun Ministerial: Developing Countries and Their Evolving Coalitions in the WTO', The World Economy 27.7: 947-966 
Ndubai, J. (2019) 'If Developing Countries Are Not Listened to at the OECD, They Will Vote With Their Feet', International Centre for Tax and Development (ICTD) blog, 28 November, https://www.ictd.ac/blog/developing-countries-oecd-inclusive-frameworkconsensus/

OECD (2020a) On-Line Guide to OECD Intergovernmental Activity, https://oecdgroups.oecd.org/Bodies/ListByDirectorateView.aspx?book=true

OECD (2020b) Tax Co-operation for Development: Progress Report, http://www.oecd.org/tax/tax-global/tax-co-operation-for-development-progressreport.htm

OECD (2018) Additional Guidance on the Attribution of Profits to Permanent Establishments, BEPS Action 7, https://www.oecd.org/tax/transfer-pricing/additional-guidanceattribution-of-profits-to-permanent-establishments-BEPS-action-7.pdf

OECD (2014) OECD Secretary-General Report to the G20 Leaders, http://www.g20.utoronto.ca/2014/OECD secretary-generals report tax matters.pdf

OEEC (1956) Draft Report of the Ad Hoc Group of Experts of Fiscal Questions (IR40/19035), OEEC; London: The National Archives

Picciotto, S. (2018) Problems of Transfer Pricing and Possibilities for Simplification, ICTD Working Paper 86, Brighton: Institute of Development Studies

Picciotto, S. (2015) 'Indeterminacy, Complexity, Technocracy and the Reform of International Corporate Taxation', Social \& Legal Studies 24.2: 165-184

Putnam, R. D. (1988) ‘Diplomacy and Domestic Politics: The Logic of Two-Level Games', International Organization 42.3: 427-460

Quinones Cruz, N. (2012) 'Colombia', in M. Lang, P. Pistone, J. Schuch and C. Staringer (eds.), The Impact of the OECD and UN Model Conventions on Bilateral Tax Treaties, Cambridge University Press: 294-307

Schreier, M. (2012) Qualitative Content Analysis in Practice, SAGE Publications Ltd

Seabrooke, L. and Wigan, D. (2016) 'Powering Ideas through Expertise: Professionals in Global Tax Battles', Journal of European Public Policy 23.3: 357-374

Shaffer, G., Sanchez, M. R. and Rosenberg, B. (2008) 'The Trials of Winning at the WTO: What Lies behind Brazil's Success', Cornell International Law Journal 41.2

Sharman, J. C. (2006) Havens in a Storm: The Struggle for Global Tax Regulation, 1st ed., Cornell University Press

Valderrama, I. J. M. (2018) 'Output Legitimacy Deficits and the Inclusive Framework of the OECD/G20 Base Erosion and Profit Shifting Initiative', Bulletin for International Taxation 72.3: 160-170

Vickers, B. (2013) 'Africa and the Rising Powers: Bargaining for the 'Marginalized Many', International Affairs 89.3: 673-693

Wijnen, W. and de Goede, J. (2014) 'The UN Model in Practice 1997-2013', Bulletin for International Taxation 68.3 